\title{
VARIASI BAHASA YANG DIGUNAKAN OLEH KALANGAN WARIA KOTA MERAUKE
}

\author{
Margaretha F. Narahawarin \\ narahawarin_fkip@unmus.ac.id \\ Sri Winarsih \\ sriwinarsih@unmus.ac.id \\ Marni Bawawa \\ marnibawawa@unmus.ac.id \\ Program Studi Sastra Inggris
Universitas Musamus
}

\begin{abstract}
Abstrak
Variation of languages used transvestites in Merauke city to interacting is very unique and very interesting to study, because in daily communication transvestites often change (switch) languages, from one to another language so this research aims to classify the variation of languages and their functions used by transvestites of Merauke city.This research is a qualitative descriptive study with object of the research is transvestites as informants. Data collection techniques usesociolinguistic research are observe critically method, survey method, and interview method. The data analysis technique was performed using the analysis model by Miles and Huberman namely data reduction, data display, and verification.The results showed that based on the classification in variations of language used by transvestites are: 1) jargon, 2) slang, 3) acronyms, and 4) forms of puns. Whereas the function of language variation used by transvestites are: 1) creating humor, 2) insinuating or mocking, 3) intimidating / familiarizing the relationship, 4) keeping to certain information, 5) refined to something that considered vulgar or taboo, and 6) expressing attitude and feelings of the heart.
\end{abstract}

Keywords: variation of language, function of language variation,transvestites

\section{PENDAHULUAN}

Bahasa ialah alat komunikasi manusia dalam melakukan interaksi dengan sesamanya dan lingkungan sosialnya. Menurut Fodor (1974:15) bahasa adalah sistem simbol dan tanda. Sistem simbol adalah hubungan simbol dengan makna yang bersifat konvesional, sedangkan sistem tanda adalah bahwa hubungan tanda dan makna bukan konvesional 
tetapi ditentukan oleh sifat atau ciri tertentu yang dimiliki benda atau situasi yang dimaksud. Hal berupa simbol dan tanda dapat kita jumpai dalam kehidupan sehari-hari dan dapat dikaji karena bahasa merupakan bagian dari linguistik.

Linguistik merupakan ilmu atau studi tentang bahasa. Pernyataan tersebut sejalan dengan Jendra (2010:5) yang mengatakan studi bahasa adalah untuk memperoleh pengertian yang selengkapnya tentang gejala bahasa secara umum. Hal seperti ini dapat dicapai dengan penelitian dalam berbagai bahasa, yakni penelitian bentuk-bentuk fisik sebagai ekspresi gejala bahasa. Penyelidikan bahasa selalu berarti kajian pemakaian bahasa dalam suatu masyarakat tertentu. Dalam bidang linguistik yang berhubungan dengan pemakaian bahasa merupakan salah satu bagian dari bidang studi sosiolinguistik (Mashun, 2005:202).

Sosiolinguistik adalah studi atau pembahasan tentang hubungan masyarakat dengan bahasa. Sosiolinguistik merupakan bagian dari linguistik yang berkaitan dengan bahasa sebagai gejala sosial dan gejala kebudayaan (Trudgill, 1974:32). Pernyataan tentang sosiolinguistik di atas menunjukkan kekuatan bahasa dalam penggunaannya oleh masyarakat. Sebagai gejala sosial, bahasa tidak dapat dipisahkan dari faktor kemasyarakatan yang sadar ataupun tidak sadar hasilnya akan beragam dari setiap penutur. Salah satu bentuk pemakaian variasi bahasa yang dipengaruhi faktor sosial di dalam komunikasi dapat dilihat dari penggunaan berbagai variasi bahasa di kalangan waria Kota Merauke.

Variasi bahasa merupakan sejenis ragam bahasa yang pemakaiannya disesuaikan dengan fungsi dan situasinya, tanpa mengabaikan kaidah-kaidah pokok yang berlaku dalam bahasa yang bersangkutan (Padmadewi 2014:7). Hubungan antara faktor-faktor sosio-situasional di dalam pemakaian bahasa, serta terjadinya saling mempengaruhi antara kaidah-kaidah gramatikal dan norma-norma pemakaian sesuai dengan fungsi dan situasinya.

Salah satu ragam atau variasi bahasa yang kita kenal adalah variasi sosial atau sosiolek. Variasi ini disebabkan oleh perbedaan sosiologis. Variasi ini menyangkut semua permasalahan pribadi penuturnya seperti usia, pendidikan, seks, pekerjaan, tingkat kebangsawanan, keadaan sosial ekonomi, dan sebagainya. Dalam variasi sosial yang berkenaan dengan tingkat, status, golongan, dan kelas sosial penuturnya terdapat beberapa varasi bahasa seperti akrolek, basilek, vulgar, slang, kolokial, jargon, argot, dan ken. Waria merupakan salah satu komunitas yang eksistensinya tidak diragukan di dalam masyarakat dan sebagai salah satu penyumbang dalam penggunaan variasi bahasa terbesar, bahasa- 
bahasa baru yang mereka ciptakan terbilang unik dan selain unik kosakata-kosakata mereka susah dipahami oleh masyarakat pada umumnya. Waria termasuk dalam bagian LGBT (Lesbi, Gay, Bisekusal, Transgender dan Transeksual) yang secara biologis berkelamin laki-laki tetapi berpenampilan serta berperilaku seperti perempuan.

Berdasarkan hasil penelitian yang dilakukan oleh peneliti terhadap kalangan waria Salon Ona di kota Merauke, penggunaan variasi bahasa waria sangatlah unik. Variasi bahasa yang diciptakan tidak semata-mata untuk merusak tata bahasa baku atau resmi, melainkan untuk menjadi identitas diri yang membedakan kalangan waria dengan masyarakat umum. Selain itu variasi bahasa waria ini dapat dikaji secara linguistik baik dari segi fonologi, morfologi, sintaksis, bahkan makna setiap kata dan kalimat pada suatu ujarannya.

Dalam penelitian ini, peneliti memilih variasi bahasa karena sifat bahasa yang bersifat arbitrer dapat memudahkan para penutur bahasa menggunakan atau menciptakan bahasabahasa baru sehingga kosakata-kosakata bahasa menjadi bertambah. Mengapa variasi bahasa di kalangan waria yang peneliti ambil karena waria merupakan suatu komunitas di dalam masyarakat yang memiliki eksistensi tersendiri, bahasa yang mereka gunakan juga terbilang sulit untuk dipahami khalayak umum, dan sudah pasti di luar kalangan waria banyak yang penasaran dan ingin mengetahui bentuk, fungsi, dan makna variasi bahasa yang mereka ciptakan.

Olehkarenaitu, mengingatpentingnyasebuahpenelitiandalam mengembangkan ilmu bahasamakapenelitimemiliki tujuan penelitian untuk menemukan variasi bahasa dan fungsinya yang digunakan oleh kalangan waria kota merauke.

\section{METODOLOGI}

Penelitianinimenggunakandeskriptifkualitatif yangdilaksanakan di Salon OnajalanIrian SeringguKabupatenMeraukeselama 4 bulan, daribulan September 2019 - Desember 2019. Salon Ona merupakan salah satu salon yang rata-rata para waria sering berkumpul dan malakukan aktivitas sehari-hari sebagi pengelola salon.

Denganmenggunakanpurposive

samplingsebagaiteknikmenentukanrespondensebagaisumberinformasi, peneliti mengambil empat oranga waria sebagai informan dengan bertujuan untuk memperoleh keterangan tentang variasi bahasa yang mereka gunakan dalam berinteraksi.

Penelitianinimenggunakanpengumpulan data dengan tiga metode yang digunakan untuk penelitian sosiolinguistik yaitu metode simak yang berupa 1) metode simak atau 
observasi dilakukan dengan menyimak penggunaan bahasa, 2) Metode survey dilakukan dengan menyebarkan daftar pertanyaan yang terstruktur untuk memperoleh informasi dari informan, dan 3) Metode wawancara dilakukan dengan cara melakukan percakapan antara peneliti dengan informan.

Sedangkan teknik analisis data menggunakan model Miles dan Hubermen. Model tersebut mencakup tiga aktivasyaitu data reduction, data display, dan verivication.

\section{PEMBAHASAN}

Data yang diuraikan dalam penelitan ini yaitu variasi bahasa yang digunakan oleh kalangan waria kota Merauke yang kosakatanya diambil dari kosakata bahasa yang hidup di lingkungan para waria. Terjadinya keragaman bahasa disebabkan bukan hanya karena para penuturnya yang tidak homogen, akan tetapi dikarenakan interaksi sosial yang dilakukan sangat bervariasiatau beragam. Keragaman bahasa di kalangan waria jelas semakin bertambah jikalau bahasa yang digunakan oleh penutur yang begitu banyak dalam kalangan waria.

\section{Variasi Bahasa yang digunakan oleh Kalangan Waria}

Setiap pengguna bahasa memiliki variasi bahasanya masing-masing sama halnya dengan para waria. Pembentukkan kosakata bahasa dan maknanya sangatlah beragam dan semuanya bergantung pada kreativitas pengguna dan disesuaikan dengan topik pembicaraan. Adapun variasi bahasa yang digunakan oleh kalangan waria dapat diklasifikasikan ke dalam bentuk jargon, slang, akronim, dan bentuk plesetan.

\subsection{Jargon}

Jargon merupakan kosakata yang khas yang dipakai dalam bidang kehidupan tertentu, seperti yang dipakai oleh montir-montir mobil, tukang kayu, guru bahasa, dan sebagainya, dan yang tidak dipakai dan sering tidak digunakan oleh orang dari bidang lain (Kridalaksana, 2008:98). Jargon yang digunakan oleh kalangan waria lebih khusus pada pekerjaan mereka sebagai pengelola salon, artinya bahwa jargon digunakan oleh sesama waria pada saat ada pelanggan yang datang ke salon.

Tabel 1.1 Bahasa Waria dalam Bentuk Jargon

\begin{tabular}{|c|c|c|}
\hline No. & Jargon & Arti \\
\hline \multicolumn{3}{|c|}{ Kategori Jargon 1 (J1) } \\
\hline 1 & Rembong & Rambut \\
\hline 2 & Cecong & Cuci \\
\hline 3 & Kerajaan & Kerja \\
\hline 4 & Jelita & Jelek \\
\hline
\end{tabular}




\begin{tabular}{|c|l|l|}
5 & Bayangkari & Bayar \\
6 & Maharani & Mahal \\
7 & Mursida & Murah \\
\hline \multicolumn{3}{|c|}{ Kategori Jargon 2 (J2) } \\
\hline 8 & Sepiola & Sepi \\
9 & Ramayana & Ramai \\
10 & Panasonic & Panas \\
\hline \multicolumn{3}{|c|}{ Kategori Jargon 3 (J3) } \\
\hline 11 & RambutanDasyat & RambutnyaTebal \\
12 & BawangGoreng & Babau/Berbau \\
\hline
\end{tabular}

Tabel 1.1 menunjukkan variasi bahasa waria dalam bentuk jargon yang digunakan dalam berinteraksi dibagi ke dalam tiga kategori sesuai dengan proses pembentukannya. Jargon pada kategori J1 memiliki bentuk yang sama dengan pengertian jargon, jargon pada kategori J2 memiliki bentuk plesetan, dan jargon pada kategori J3 memiliki bentuk frase. Sebagai contoh, salah satu waria berbicara pada teman warianya "cecong rembong dulu baru pake obat smoothing" yang artinya 'cuci dulu rambutnya baru pakai obat pelurus rambut'.

\subsection{Slang}

Slang adalah variasi bahasa yang dibuat oleh sekelompok masyarakat tertentu yang dipergunakan sebagai babahasa dalam pergaulan dengan sesama komunitas pemakai bahasa tersebut (Padmadewi, Ni Nyoman; Merlina, P.D.; Saputra, N.P.H, 2014:9). Slang yang digunakan oleh para waria di Salon Ona merupakan slang yang digunakan oleh kalangan waria pada umumnya.

Tabel 1.2 Bahasa Waria dalam Bentuk Slang

\begin{tabular}{|c|c|c|}
\hline No & Slang & Arti \\
\hline \multicolumn{3}{|c|}{ Kategori Slang 1 (S1) } \\
\hline 1 & Lekong & Laki-Laki \\
\hline 2 & Cuco & Ganteng \\
\hline 3 & Pewong,Ngalang & Perempuan \\
\hline 4 & Celong & Kecil \\
\hline 5 & Sutra & Sudah \\
\hline 6 & Gedong & Besar \\
\hline 7 & Kentong & KemaluanLaki-Laki \\
\hline 8 & Kencana & Buang Air Kecil/ Pipis \\
\hline 9 & Capcus & Cepat \\
\hline 10 & Tamara & Tamu \\
\hline 11 & Tinta & Tidak Ada \\
\hline 12 & Gegong & Gigi \\
\hline 13 & Polandia & Pulang \\
\hline 14 & Wandu & Waria \\
\hline
\end{tabular}




\begin{tabular}{|c|c|c|}
\hline & & \\
\hline 15 & Suminarti & Suami \\
\hline 16 & Hompimpa & Handphone \\
\hline 17 & Sindang & Sini \\
\hline 18 & Tami & Minum \\
\hline 19 & Esong & Isap \\
\hline 20 & Pepong & KelaminWanita \\
\hline 21 & Sumpu & Banyak \\
\hline 22 & Rexona & Rokok \\
\hline 23 & Belalang & Beli \\
\hline 24 & Metong & Mati \\
\hline 25 & Orcit & Jelek \\
\hline & & (S2) \\
\hline 26 & Tami-Tami & Minum-Minum \\
\hline 27 & Wara-Wara & Perhiasan \\
\hline & & (S3) \\
\hline 28 & Kesindang & Kesini \\
\hline 29 & Disindang & Di sini \\
\hline & & (S4) \\
\hline 30 & Bebong & Babi \\
\hline 31 & Anjonjeng & Anjing \\
\hline & & (S5) \\
\hline 32 & GilinganPadi & Gila \\
\hline 33 & Lapangan Bola & Lapar \\
\hline 34 & Brenda Kasih & BAB \\
\hline 35 & PelitaKasih & Pelit \\
\hline & & (S6) \\
\hline 36 & Orakori & Tidakadauang \\
\hline 37 & OraSunarti & TidakSunat \\
\hline 38 & Wes bayangkari & Sudahbayar \\
\hline
\end{tabular}

Tabel 1.2 menunjukkan variasi bahasa waria dalam bentuk slang yang digunakan dalam berinteraksi dibagi ke dalam enam kategori sesuai dengan proses pembentukannya. Jargon pada kategori S1 memiliki bentuk yang sama dengan pengertian slang. Slang pada kategori S2 memiliki bentuk pengulangan atau reduplikasi. Slang pada ketegori S3 memiliki bentuk afiksasi atau imbuhan, artinya bahwa kata slang "sindang" yang memiliki arti 'sini' diberi imbuhan ke- dan di- sehingga menjadi ke sindang atau di sindang. Slang pada kategori S4 merupakan slang nama hewan, slang ini digunakan untuk sebuah kata yang negatif seperti makian. Slang pada kategori S5 merupakan bentuk frase. Sedangkan slang pada kategori S6 merupakan bentuk campur kode, artinya terdapat campuran antara bahasa Jawa dan kata slang milik waria, seperti "Ora" dalam bahasa Jawa yang artinya 'tidak' dan “Wes” artinya 'sudah'.

\subsection{Akronim}


Akronim adalah kependekan yang berupa gabungan huruf atau suku kata atau bagian lain yang ditulis dan dilafalkan sebagai kata yang sesuai dengan kaidah fonotatik bahasa bersangkuan (Kridalaksana, 2008:5). Dalam berinteraksi para waria juga menggunakan akronim dalam berkomuikasi antar sesamanya.

Tabel 1.3 Bahasa Waria dalam Bentuk Akronim

\begin{tabular}{|c|l|l|}
\hline No. & \multicolumn{1}{|c|}{ Akronim } & \multicolumn{1}{c|}{ Arti } \\
\hline 1 & Juldir & JualDiri \\
2 & Hitaci & HitamTapiCantik \\
3 & Hadija & Hati-hati di Jalan \\
\hline
\end{tabular}

Tabel 1.3 memuat tentang akronim yang digunakan berkomunikasi antar sesma waria. Akronim yang digunakan waria terbilang cukup sedikit dibandingkan dengan bentuk jargon, slang, dan plesetan.

\subsection{Bentuk Plesetan}

Plesetan merupakan bentuk dalam situasi tidak resmi yang pembentukannya menggunakan lambang dan istilah tertentu yang tentu saja ingin memaknakan sesuatu. Plesetan mengutamakan atau memanfaatkan secara maksimal pembentukan berbagai pertanyaan dan aneka makna secara maksimal pembentukkan berbagai pernyataan dan aneka makna secara "sewenang-wenang" karena memiliki kaitan dengan makna sebenarnya.

Tabel 1.4 Bahasa Wariadalam Bentuk Plesetan

\begin{tabular}{|c|l|l|}
\hline No. & \multicolumn{1}{|c|}{ Kata } & \multicolumn{1}{|c|}{ Bentuk Asli } \\
\hline 1 & Lesbiola & Lesbian \\
2 & Jelong-Jelong & Jalan-Jalan \\
3 & Sunarti & Sunat \\
4 & Makarena & Makanan \\
5 & Mandala & Mandi \\
6 & Lambreta & Lama \\
7 & Anjonjeng & Anjing \\
8 & Tidore & Tidur \\
9 & Kondisioner & Kondom \\
10 & Sakina & Sakit \\
11 & Setong & Satu \\
12 & Hitaci & Hitam \\
13 & Gatalia & Gatal \\
14 & Pendekar & Pendek \\
15 & Habiba & Habis \\
16 & Celeno & Celana \\
17 & Motorola & Motor \\
\end{tabular}




\begin{tabular}{l|l|l|}
18 & Jahara & Jahat \\
19 & Mabora & Mabok/Mabuk \\
20 & Lontang & Lonte \\
\hline
\end{tabular}

Tabel 1.4 memuat tentang bentuk plesetan yang digunakan oleh para waria dan terlihat mereka sangat kreatif dalam penggunaan bahasa sehingga kata-kata yang sudah ada dalam bahasa Indonesia mereka mengubahnya ke dalam bentuk plesetan tanpa merubah makna aslinya.

\section{Fungsi Variasi Bahasa yang digunakan oleh Kalangan Waria}

Secara umum bahasa berfungsi sebagai alat untuk berekspresi, berkomunikasi, dan melakukan integrasi dalam adaptasi sosial. Sedangkan,secara khusus fungsi bahasa untuk melakukan hubungan dalam pergaulan sehari-hari.

Fungsi bahasa memiliki peran utama sebagai sarana dalam beromunikasi. Komunikasi dilakukan oleh manusia karena manusia merupakan makhluk sosial. Manusia yang merupakan makhluk sosial selalu dituntut untuk berinteraksi dengan manusia yang lain. Dalam berinteraksi dibutuhkan alat bantu untuk menjalin hubungan dengan individu yang lain. Berdasarkan hal tersebut maka muncullah apa yang disebut dengan variasi bahasa. Variasi bahasa dengan sendirinya muncul karena proses interaksi sosial dari para pelaku bahasa yang beragam sehinggga variasi bahasa memiliki fungsi penggunaanya. Fungsi variasi bahasa yang digunakan oleh kalangan waria ada enam yaitu: menciptakan humor, menyindir atau mengejek, mengintimkan/mengakrabkan hubungan, merahasiakan informasi tertentu, menghaluskan sesuatu yang dianggap vulgar atau tabu, mengungkapkan sikap dan perasaan hati.

\subsection{Menciptakan Humor}

Penggunaan variasi bahasa pada situasi ini sering digunakan dalam berinteraksi, para waria sering menggunakan bahasa mereka dengan sesama waria atau dengan teman yang sudah mengetahui bahasa waria seperti penggunaan slang "racun" dalam pembicaraan "kenapa harus ada racun-racun yang menjadi penghalang untuk kita", racun-racun yang dimaksudkan adalah perempuan normal yang menjadi saingan para waria untuk dekat dengan para lelaki. Atau dengan contoh lain dengan menggunakan akronim hitaci "ginigini hitaci loh (biar hitam tapi cantik)“. Bahasa yang digunakan oleh kalangan waria adalah menggunakan bahasa yang menciptakan humor bagi lawan bicara yang mendengar.

\subsection{MenyindiratauMengejek}


Penggunaan variasi bahasa pada situasi ini terjadi pada saat seorang wanita pergi ke salon untuk menggunting rambut, sehingga seorang waria yang melayani pelanggannya berbicara dengan salah satu teman waria yang mengerti bahasa mereka dengan pembicaraan "cantik-cantik rembong bawang goreng (cantik-cantik tapi rambutnya bau)".

Bahasa yang digunakan oleh kalangan waria adalah fungsi variasi bahasa yang menyindir atau mengejek pelanggan salon, tetapi menyindir atau mengejek tidak secara langsung karena tidak ingin pelanggan salon tersinggung.

\subsection{Mengintimkan/MengakrabkanHubungan}

Penggunaan variasi bahasa pada situasi ini sering terjadi pada saat ada pelanggan baru yang datang ke salon sehingga dalam berkomunikasi terciptalah pembicaraan yang akrab seperti "selamat datang tamara bleszynski, ada yang bisa dibantu?", makna dari pembicaraan ini adalah salam selamat datang kepada seorang pelanggan wanita. Arti lain juga terdapat pada nama artis wanita indonesia tamara bleszynski yang berhubungan dengan pelanggan wanita, sedangkan arti tamara dalam bahasa waria adalah tamu.

Bahasa yang digunakan oleh kalangan waria adalah fungsi variasi bahasa yang mengakrabkan hubungan dengan orang lain karena para waria selalu mendekatkan diri atau ingin mengakrabkan hubungan dengan siapapun.

\subsection{MerahasiakanInformasiTertentu}

Penggunaan variasi bahasa pada situasi ini juga terjadi hanya khusus di kalangan waria di Salon Ona dan berkaitan dengan urusan pribadi seperti pembicaraan rahasia yang tidak mereka sebutkan identitas seorang lelaki kepada peneliti. Pembicaraan tersebut terkait dengan "kentong ora sunarti (kemaluan lelaki yang tidak sunat)", hal ini hanya mereka yang ketahui dan dirahasiakan antara hubungan waria dengan lekong/lelaki. Bahasa yang digunakan oleh kalangan waria adalah fungsi variasi bahasa yang merahasiakan informasi tertentu.

\subsection{Menghaluskansesuatu yang dianggap vulgar atautabu}

Penggunaan variasi bahasa pada situasi ini paling sering karena kosakata dalam bahasa Indonesia mereka ciptakan dalam bahasa waria untuk penghalusan kata yang dianggap vulgar atau tabu. Kosakata tersebut seperti:

Tabel 2.5 Penghalusan kata vulgar/tabu

\begin{tabular}{|l|l|l|}
\hline No. & Bentuk asli & Penghalusan kata vulgar/tabu \\
\hline
\end{tabular}




\begin{tabular}{|l|l|l|}
\hline 1 & KemaluanLaki-Laki & Kentong \\
\hline 2 & Buang Air Kecil/ Pipis & Kencana \\
\hline 3 & KelaminWanita & Pepong \\
\hline 4 & Babau/Berbau & BawangGoreng \\
\hline 5 & Anjing & Anjonjeng \\
\hline 6 & Lonte & Lontang \\
\hline 7 & Gila & GilinganPadi \\
\hline 8 & BAB/ buang air besar & Brenda Kasih \\
\hline
\end{tabular}

Penghalusan ini digunakan berdasarkan konteks yang ada. Seperti kita ketahui ketika seseorang ingin minta ijin ke toilet, selalu mengatakan "ijin ke belakang (buang air kecil/besar)". Hal ini juga terjadi kepada para waria pada saat melayani pelanggan salon selalu mengucapakan "brenda kasih (BAB)" atau "kencana (pipis)" sehingga bahasa yang digunakan oleh kalangan waria adalah fungsi variasi bahasa yang menghaluskan sesuatu yang dianggap vulgar atau tabu.

\subsection{Mengungkapkansikapdanperasaanhati}

Penggunaan variasi bahasa untuk mengungkapkan sikap dan perasaan hati sering terjadi karena dalam situasi apapun pengguna bahasa dapat mengekspresikan emosi mereka melalui berkomunikasi. Emosi yang dimaksudkan dalam hal ini adalah emosi ketika kita merasa bahagia, marah, atau yang lainnya. Hal yang terihat dalam mengungkapkan sikap dan perasaan hati yang dialami oleh waria adalah perasaan bahagia ketika ada seorang pelanggan salon yang memberikan tip atau yang dikenal dengan memberi uang lebih kepada pelayan. Melalui peristawa ini ungkapan bahagia diucapkan kepada sesama waria "wedo indang sutra bayangkari tapi aku dikasih tip lagi (perempuan itu sudah bayar tapi saya dikasih lagi tip)"

\section{SIMPULAN}

Penelitianinimerupakanpenelitianbidanglinguistik yang menggalitentangvariasi bahasa. Variasi bahasa yang digunakan dalam berinteraksi sangatlah bervariasi dan unik. Hasilpenelitianmenunjukkanbahwaterdapatvariasi bahasa yang diklasifikasikanberdasarkanbentuk jargon, slang, akronim, dan bentuk plesetan.

Variasi bahasa yang diklasifikasikan memiliki fungsi penggunaanya dalam berinteraksi, fungsi ada enam yaitu: 1) menciptakan humor, 2) menyindir atau mengejek, 3) mengintimkan/mengakrabkan hubungan, 4) merahasiakan informasi tertentu, 5) menghaluskan sesuatu yang dianggap vulgar atau tabu, 6) mengungkapkan sikap dan perasaan hati. 


\section{DAFTAR PUSTAKA}

Chaer, A. dan L. Agustina. 2010. Sosiolinguistik Perkenalan Awal. Jakarta: Rineka Cipta.

Chaer, A. dan L. Agustina. 1995. Linguistik Umum.Jakarta: Rineka Cipta.

Crystal, David. 1992. The Varitation Language and Cambridge Encyclopedia of the English Language. Cambridge University Press.

Depdikbud. 2007. Fungsi Umum Bahasa Indonesia. Gramedia: Pustaka Indonesia.

Fodor T. Bever and M. Garrett. 1974. The Psycology of Language, McGraw Hill.

Jendra, M. I. I. 2010. Sociolinguistics: The Study of Societies Languages. Yogyakarta: Graha Ilmu.

Kridalaksana, Harimurti. 2001. Pembentukan Kata dalam bahasa Indonesia. Jakarta: PT. Gramedia.

Kridalaksana, Harimurti. 2008. Kamus Linguistik. PT. Jakarta: Gramedia.

Maksan, Marjusman. 1995. Ilmu Bahasa. Padang: IKIP Padang Press.

Mahsun. 2005. Metode Penelitian Bahasa: Tahapan Srategi, Metode dan Tekniknya. Edisi Refisi Jakarta: PT Gajah Grafindo Persada.

Miles, M. B. \& Huberman, A.M. (1994) Qualitative Data Analysis: An Expanded Sourcebook (2nded.) Thousand Oaks. CA: Sage Publication, Inc.

Padmadewi, Nyoman. 2014. Sosiolinguistik. Yogyakarta: Graha Ilmu.

Pateda, Mansoer. 1987. Semantik Leksikal. Bandung: Angkasa.

Sugiyono. (2015). Metode Penelitian Pendidikan Pendekatan Kuantitatif, Kualitatif, dan R\&D. Bandung: Alfabeta

Trudgill, Peter. 1974. Sociolinguistics: An Introduction Hardmonsworth: Pinguin Books Ltd. 